\title{
Ebb-and-flow Subirrigation Strategies Increase Biomass and Nutrient Contents and Reduce Nitrate Levels in Lettuce
}

\author{
Leqi Yang ${ }^{1}$ \\ Department of Landscape Architecture, Shanghai Jiao Tong University, No. \\ 800 Dongchuan Road, Shanghai 200240, China
}

\author{
Xiao Yang ${ }^{1}$ \\ School of Agriculture and Biology, Shanghai Jiao Tong University, No. 800 \\ Dongchuan Road, Shanghai 200240, China
}

\author{
Hong Zhao \\ Department of Landscape Architecture, Shanghai Jiao Tong University, No. \\ 800 Dongchuan Road, Shanghai 200240, China
}

\author{
Danfeng Huang \\ School of Agriculture and Biology, Shanghai Jiao Tong University, No. 800 \\ Dongchuan Road, Shanghai 200240, China
}

\author{
Dongqin Tang ${ }^{2}$ \\ Department of Landscape Architecture, Shanghai Jiao Tong University, No. \\ 800 Dongchuan Road, Shanghai 200240, China
}

Additional index words. Lactuca sativa, ebb-and-flow subirrigation system, irrigation frequency, immersion time, nutritional quality

\begin{abstract}
Overhead irrigation is widely used to water lettuce during commercial production in China but exerts potential water wastage and pollution. Subirrigation is thought as a water-saving, high-efficiency fertigation strategy. However, few studies have compared the nutritional value and nitrate content of lettuce grown using subirrigation with plants cultivated with overhead irrigation. Therefore, this study explored the ability of ebb-and-flow subirrigation strategies to produce high yields of a leafy lettuce (cultivar Biscia Rossa) with high nutritional value and low nitrate content. Lettuce plants were cultivated in an ebb-and-flow subirrigation system with different irrigation frequencies (every 2 or 3 days) and immersion times (5, 10 or 15 minutes); overhead irrigation was used as control. Ebb-and-flow subirrigation significantly enhanced several lettuce growth parameters, significantly increased the level of vitamin $C$, and significantly decreased the nitrate content of lettuce leaves compared with overhead irrigation. The optimal subirrigation strategy for lettuce production was irrigation every 3 days with 15 minutes immersion; this ebb-and-flow subirrigation protocol could potentially be used to save water and resources, improve yield and nutrient contents and reduce nitrate content in commercial greenhouse lettuce production.
\end{abstract}

In horticultural practice, numerous factors - such as environmental conditions, agricultural management, harvest time, and irrigation and fertilization strategies-affect the production and chemical composition of vegetable crops (Tavarini and Angelini, 2013). Water management is a key determinant of both the biomass and nutritional

Received for publication 12 Mar. 2018. Accepted for publication 11 May 2018.

This work was supported by the National Natural Science Foundation of China (No. 61233006) and National High-Tech Research and Development Program of China (863 Program) (2013AA103006).

${ }^{1}$ L.Y. and X.Y. contributed equally to this work.

${ }^{2}$ Corresponding author. E-mail: dqtang@sjtu.edu.cn. irrigation management techniques that enable optimal crop production.

Subirrigation is a water-saving, highefficiency fertigation strategy in which intelligent control enables sustainable use of both water and fertilizers; however, the initial cost of automated subirrigation systems is high (Ferrarezi et al., 2015a; Thomas, 1993). Ebb-and-flow subirrigation is relatively cheap and easy-to-use compared with other subirrigation systems and is recognized as a high water productivity strategy. Ebband-flow system can adjust the water and fertilizer depending on the requirement of crop and reduce the overall water and nutrient use (Ferrarezi et al., 2015b). For instance, Holcomb et al. (1992) reported that ebb-andflow systems reduce the use of water and fertilizer by $40 \%$ in the production of Hedera helix. In addition, ebb-and-flow systems have been associated with lower occurrence of foliar and soil-borne diseases and groundwater contamination (Thomas, 1993). Moreover, automatic control of fertigation reduces labor costs and provides a potential economic benefit (Ferrarezi et al., 2015a).

Lettuce is a significant source of many nutrients and has been reported to exert antioxidant (Yang et al., 2017), antihepatitis B virus (Cui et al., 2017), anti-inflammatory (Pepe et al., 2015), and antidiabetic (Cheng et al., 2014) effects. However, leafy vegetables, such as spinach and lettuce, represent significant sources of nitrate in the human diet, providing $\approx 40 \%$ to $92 \%$ of the average daily intake of nitrate and its metabolite nitrite $(14 \%$ to $43 \%$ of daily dietary intake) (Liu et al., 2014; Qadir et al., 2017). Therefore, high levels of nitrate in lettuce crops may be harmful to human health because of the toxicity of its downstream metabolites nitrite, nitrosamines, and nitrosamides (Santamaria, 2006).

Numerous studies have investigated the nutrient requirements, water use, and growth of lettuce cultivated in ebb-and-flow systems. Soundy et al. (2001a, 2001b) suggested appropriate concentrations of phosphorus and potassium after lettuce transplantation using an ebb-and-flow system. Ahmed et al. (2000) reported ebb-and-flow subirrigation led to significantly taller lettuce plants and saved $\approx 86 \%$ of the water used by overhead irrigation. However, little research has compared the nutritional value and nitrate content of lettuce grown using an ebb-and-flow system with plants cultivated with overhead irrigation.

In this study, we aimed to develop an ebb-and-flow subirrigation strategy for commercial greenhouse lettuce production that results in high yields of healthy plants with high contents of potentially healthpromoting compounds - such as vitamin C, chlorophyll, sugar, and proteins - and a safe nitrate content.

\section{Materials and Methods} tive effects, e.g., water wastage and potentia pollution of the soil surface and groundwater with pesticides and fertilizers (Ferrarezi et al., 2015a). Therefore, the challenge remains to develop environmentally friendly
Subirrigation system. The ebb-and-flow subirrigation system used in this study consisted of three layers of waterproof benches, 
Table 1. Plant growth characteristics of lettuce subjected to different ebb-and-flow subirrigation strategies.

\begin{tabular}{|c|c|c|c|c|c|c|}
\hline Treatment & Fresh wt (g/plant) & Dry wt (g/plant) & Plant ht $(\mathrm{cm})$ & Leaf length $(\mathrm{cm})$ & Leaf width $(\mathrm{cm})$ & Water content $(\%)$ \\
\hline Control & $3.80 \pm 0.21 \mathrm{f}$ & $0.23 \pm 0.01 \mathrm{~d}$ & $14.37 \pm 0.55 \mathrm{e}$ & $12.57 \pm 0.55 \mathrm{e}$ & $5.43 \pm 0.40 \mathrm{c}$ & $93.86 \pm 0.47 \mathrm{c}$ \\
\hline $2 \mathrm{~d} / 5$ & $5.75 \pm 0.15 \mathrm{e}$ & $0.32 \pm 0.01 \mathrm{c}$ & $15.83 \pm 0.40 \mathrm{~d}$ & $14.20 \pm 0.46 \mathrm{~d}$ & $6.27 \pm 0.25 b$ & $94.36 \pm 0.17 \mathrm{c}$ \\
\hline $2 \mathrm{~d} / 10$ & $6.35 \pm 0.26 \mathrm{~d}$ & $0.23 \pm 0.01 \mathrm{~d}$ & $16.37 \pm 0.61 \mathrm{~cd}$ & $15.30 \pm 0.40 \mathrm{c}$ & $6.66 \pm 0.21 \mathrm{ab}$ & $96.39 \pm 0.26 \mathrm{ab}$ \\
\hline $2 \mathrm{~d} / 15$ & $7.33 \pm 0.25 \mathrm{c}$ & $0.21 \pm 0.01 \mathrm{~d}$ & $18.00 \pm 0.62 \mathrm{a}$ & $16.10 \pm 0.66 \mathrm{bc}$ & $6.77 \pm 0.35 \mathrm{ab}$ & $97.13 \pm 0.04 \mathrm{a}$ \\
\hline $3 d / 5$ & $6.41 \pm 0.02 \mathrm{~d}$ & $0.39 \pm 0.21 b$ & $15.57 \pm 0.65 \mathrm{~d}$ & $14.17 \pm 0.47 \mathrm{~d}$ & $6.53 \pm 0.67 \mathrm{ab}$ & $93.99 \pm 0.23 \mathrm{c}$ \\
\hline $3 \mathrm{~d} / 10$ & $7.79 \pm 0.30 b$ & $0.42 \pm 0.01 \mathrm{a}$ & $16.97 \pm 0.60 \mathrm{bc}$ & $16.40 \pm 0.56 \mathrm{ab}$ & $7.13 \pm 0.50 \mathrm{a}$ & $94.56 \pm 0.28 \mathrm{c}$ \\
\hline $3 \mathrm{~d} / 15$ & $8.87 \pm 0.09 \mathrm{a}$ & $0.36 \pm 0.02 \mathrm{bc}$ & $17.93 \pm 0.42 \mathrm{ab}$ & $17.13 \pm 0.25 \mathrm{a}$ & $7.23 \pm 0.55 \mathrm{a}$ & $95.97 \pm 0.24 b$ \\
\hline
\end{tabular}

Control plants were subjected to overhead irrigation. Values are mean \pm SD of five replications. Different letters represent significant differences at $P<0.05$ (least significant difference). $2 \mathrm{~d} / 5=$ every $2 \mathrm{~d}$ with 5 min immersion; $2 \mathrm{~d} / 10=$ every $2 \mathrm{~d}$ with 10 min immersion; $2 \mathrm{~d} / 15=$ every $2 \mathrm{~d}$ with $15 \mathrm{~min}$ immersion; $3 \mathrm{~d} / 5=$ every $3 \mathrm{~d}$ with $5 \mathrm{~min}$ immersion; $3 \mathrm{~d} / 10=$ every $3 \mathrm{~d}$ with $10 \mathrm{~min}$ immersion; $3 \mathrm{~d} / 15=$ every $3 \mathrm{~d}$ with $15 \mathrm{~min}$ immersion.

an electric timer, a fertilizer solution reservoir, an artificial lighting system, and a pump. The length, width, and height of the system were $6.5 \mathrm{~m}, 0.6 \mathrm{~m}$, and $1.8 \mathrm{~m}$, respectively. The three cultivation benches in each layer were periodically flooded with water (or water-soluble fertilizer solution) using the pump. Each bench was $2 \mathrm{~m}$ long, $0.6 \mathrm{~m}$ wide and $0.06 \mathrm{~m}$ deep. The slice gap of each layer is $0.8 \mathrm{~m}$.

Plant materials. Seeds of the widely cultivated, relatively high economic value, purple leafy lettuce cultivar Biscia Rossa were purchased from Franchi Sementi Ltd. Co., Milan, Italy. Seeds were sown in 200hole trays (one seed per hole) in seedling substrate (NPK $\geq 2 \%$, organic matter $\geq 40 \%$; Zhongnuo Agriculture R\&D Company, Huai'an, China) in the ebb-and-flow system in a greenhouse at the Shanghai Jiao Tong University, China (lat. $31^{\circ} 12^{\prime} \mathrm{N}$, long. $\left.121^{\circ} 38^{\prime} \mathrm{E}\right)$. Fourteen-day-old seedlings with the third true leaves were transplanted into trapezoidal plastic containers (sides: $20 \times 20$ $\mathrm{cm}$; base: $20 \times 12 \mathrm{~cm}$; height, $12 \mathrm{~cm}$ ) containing $15 \%$ organic fertilizer (NPK $\geq 6 \%$, organic matter $\geq 45 \%$; Zhongnuo) and $85 \%$ seedling substrate.

Various ebb-and-flow system subirrigation strategies lasting $30 \mathrm{~d}$ with different irrigation frequencies and immersion times were programmed: irrigation every $2 \mathrm{~d}$ with $5 \mathrm{~min}$ immersion $(2 \mathrm{~d} / 5)$; every $2 \mathrm{~d}$ with $10 \mathrm{~min}$ immersion $(2 \mathrm{~d} / 10)$; every $2 \mathrm{~d}$ with $15 \mathrm{~min}$ immersion ( $2 \mathrm{~d} / 15)$; every $3 \mathrm{~d}$ with $5 \mathrm{~min}$ immersion ( $3 \mathrm{~d} / 5)$; every $3 \mathrm{~d}$ with 10 min immersion $(3 \mathrm{~d} / 10)$, and every $3 \mathrm{~d}$ with $15 \mathrm{~min}$ immersion $(3 \mathrm{~d} / 15)$. Control samples were subjected to overhead irrigation every $3 \mathrm{~d}$ (Con). All treatments (four seedlings per treatment, five replications) were arranged randomly. During the experiment, the temperature was maintained at $18 \pm 3{ }^{\circ} \mathrm{C}$ during the day and 12 $\pm 3{ }^{\circ} \mathrm{C}$ at night with a light intensity of 120 $150 \mu \mathrm{mol} \cdot \mathrm{m}^{-2} \cdot \mathrm{s}^{-1}$ (natural and artificial white lighting).

Determination of morphological indicators, fresh and dry weights and water content of lettuce. Fresh samples were harvested and morphological parameters, including plant height, leaf length and leaf width, were measured. Fresh weight (FW) and dry weight (DW) were determined using an electronic scale. Water content $(\%)$ was calculated as $(\mathrm{FW}-\mathrm{DW}) / \mathrm{FW} \times 100 \%$.

Determination of total chlorophyll and anthocyanin contents. Chlorophyll content
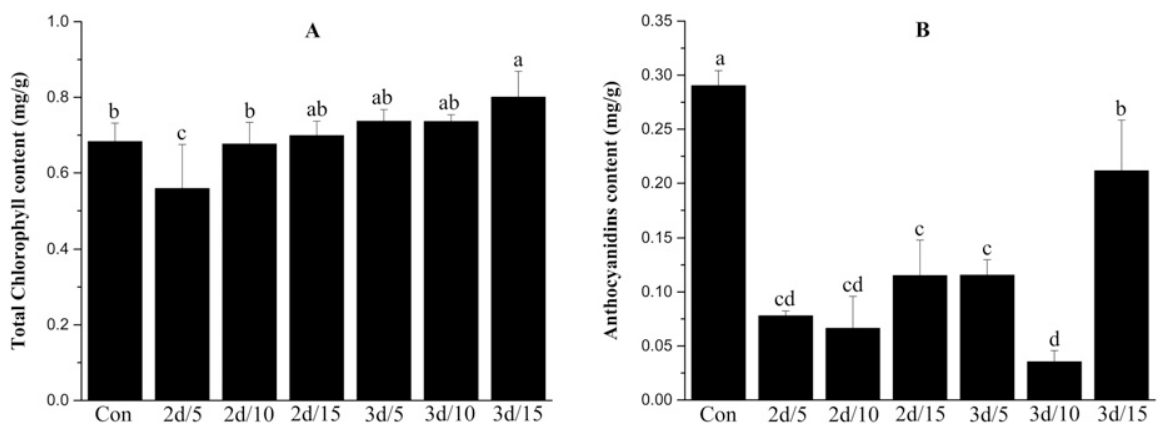

Fig. 1. Effect of different ebb-and-flow subirrigation strategies on the (A) total chlorophyll content and (B) anthocyanidin content of lettuce leaves. Control plants were subjected to overhead irrigation. Values are mean \pm SD of three replications $(n=3$ each). Different letters represent significant differences at $P<0.05$ (least significant difference analysis).

was measured as previously described (Xu et al., 2010). Briefly, leaf tissues $(0.1 \mathrm{~g})$ were placed in a $15-\mathrm{mL}$ tube containing $5 \mathrm{~mL}$ of $80 \%$ acetone and $5 \mathrm{~mL}$ of $100 \%$ ethanol and incubated in the dark at room temperature until the tissues became white. Absorbance was measured at 663, 646, and $470 \mathrm{~nm}$. A solution of $80 \%$ acetone and $100 \%$ ethanol $(1 / 1, v / v)$ was used as the blank control.

Anthocyanin content was determined using the $\mathrm{pH}$ differential method (Yang, 2007). Briefly, $1.0 \mathrm{~mL}$ of $1.0 \% \mathrm{HCl} / \mathrm{methanol}$ was added to $300 \mathrm{mg}$ of freshly ground leaf material, incubated at room temperature for $18 \mathrm{~h}$ with gentle agitation, centrifuged at $14,000 \mathrm{rpm}$ for $1 \mathrm{~min}$, and $400 \mathrm{~mL}$ of cleared supernatant was mixed with $600 \mathrm{~mL}$ of acidified methanol. Two dilution tubes of $5 \mathrm{~mL}$ of each sample were prepared. One was added to $4 \mathrm{~mL}$ of $\mathrm{KCl}$ solution (pH 1) and the other was added to $4 \mathrm{~mL}$ of $\mathrm{CH}_{3} \mathrm{COONa}(\mathrm{pH}$ 4.5). The absorption values of each sample were determined at the $\lambda_{\text {vis-max }}(530 \mathrm{~nm}$ in this study) and $700 \mathrm{~nm}$ using a double beam ultraviolet-vis spectrophotometer. The anthocyanin content was expressed as the equivalent of cyanidin-3-glucoside in $\mathrm{mg}$ per g FW.

Determination of soluble sugar and soluble protein contents. To analyze soluble sugars, $1 \mathrm{~g}$ of leaf tissue was extracted in 4 $\mathrm{mL}$ of $80 \%$ ethanol, heated in a boiling water bath for $30 \mathrm{~min}$, cooled, centrifuged at 3000 rpm for $10 \mathrm{~min}$, and the absorption value of the supernatant was determined at $620 \mathrm{~nm}$ (Lin, 1989). The concentration of soluble sugars was calculated by reference to a standard curve created using glucose.
Protein content was determined by Coomassie Brilliant Blue G-250 staining (Wang and Xing, 2009). Leaf samples $(0.5 \mathrm{~g})$ were homogenized in $5 \mathrm{~mL}$ of distilled water, centrifuged at $4000 \mathrm{rpm}$ for $10 \mathrm{~min}$, and $100 \mu \mathrm{L}$ supernatant was added to $5 \mathrm{~mL}$ Coomassie Brilliant Blue G-250 solution $(100 \mathrm{mg}$ dissolved in $50 \mathrm{~mL}$ ethanol, 100 $\mathrm{mL} 85 \%$ phosphoric acid was added, then diluted to $1 \mathrm{~L}$ with water). Absorption was assessed at $595 \mathrm{~nm}$ using an ultraviolet-vis spectrophotometer and protein content was determined using a standard curve created using bovine serum albumin.

Determination of vitamin $C$ content and nitrate concentration. Vitamin $\mathrm{C}$ content was determined as previously described (Francisco et al., 2010). Briefly, $2.0 \mathrm{~g}$ of freshly ground leaf powder was mixed with $1.0 \mathrm{~mL}$ of $\mathrm{ZnSO}_{4}(30 \%)$ and potassium ferrocyanide $\left(\mathrm{K}_{4} \mathrm{Fe}_{6} \cdot 3 \mathrm{H}_{2} \mathrm{O}, 15 \%\right)$, then $1.0 \%$ oxalic acid was added to a final volume of $100 \mathrm{~mL}$, the solution was filtered, $2.0 \mathrm{~mL}$ of 2,6-dichlorphenol indophenol and $5.0 \mathrm{~mL}$ xylene were added to $4.0 \mathrm{~mL}$ of the filtrate, the solution was vortexed, and optical density was recorded at $500 \mathrm{~nm}$.

The nitrate contents of dried samples were analyzed following the method described by Powell et al. (2000). Briefly, $0.5 \mathrm{~g}$ root tips, $5.0 \mathrm{~mL}$ of 2,3,5-triphenyltetrazolium chloride solution $(0.4 \%)$, and $5.0 \mathrm{~mL}$ of phosphate buffer were incubated at $37^{\circ} \mathrm{C}$ for $3 \mathrm{~h}$, then $2.0 \mathrm{~mL}$ of $\mathrm{H}_{2} \mathrm{SO}_{4}(1.0 \mathrm{M})$ was added to end the reaction and absorbance was assessed at $485 \mathrm{~nm}$.

Statistical analysis. Data were analyzed using SPSS 14.0 software (IBM, Armonk, 
NY); Differences among means were compared by the least significant difference test; $P<0.05$ was considered significant. The correlation was assessed using two-tailed Pearson correlation tests; $P<0.01$ and 0.05 were considered significant. Figures were created using OriginPro 2016 software (OriginLab, Northampton, MA).

\section{Results}

Effects of ebb-and-flow subirrigation strategies on the morphological characteristics, fresh and dry weights and water content of lettuce. The plant growth characteristics of lettuce subjected to different irrigation strategies are shown in Table 1. Compared with control lettuce cultivated with overhead irrigation, all ebb-and-flow treatments significantly $(P<0.05)$ increased FW. At the same irrigation frequency, longer immersion times led to significantly higher FWs. In addition, plants irrigated every $3 \mathrm{~d}$ had significantly higher FWs than plants irrigated every $2 \mathrm{~d}$. Lettuce in the $2 \mathrm{~d} / 5,3 \mathrm{~d} /$ 10 , and $3 \mathrm{~d} / 15$ treatments had significantly higher DWs than control plants. The highest FW was observed for the $3 \mathrm{~d} / 15$ treatment, which was 2.3-fold higher than control; the highest DW in $3 \mathrm{~d} / 10$ treatment was 1.8 -fold higher than control lettuce. Water content was significantly higher for the $2 \mathrm{~d} / 10,2 \mathrm{~d} / 15$, and $3 \mathrm{~d} / 15$ treatments than control. Moreover, water content was significantly higher for plants irrigated every $2 \mathrm{~d}$ than plants irrigated every $3 \mathrm{~d}$ except for treatments with immersion for $5 \mathrm{~min}$.

The various ebb-and-flow subirrigation strategies had a significantly increased effect on the plant height and leaf length and width compared with control plants (Table 1). The $3 \mathrm{~d} / 15$ ebb-and-flow subirrigation treatment led to the largest plant height, leaf length, and leaf width values $(17.93 \mathrm{~cm}, 17.13 \mathrm{~cm}$, and $7.23 \mathrm{~cm}$ ); these values were 1.2-, 1.4- and 1.3fold higher than control plants.

Effects of ebb-and-flow subirrigation strategies on the pigment contents of lettuce. Compared with control lettuce, the $2 \mathrm{~d} / 5$ ebb-and-flow treatment led to a significantly lower total chlorophyll content, the $3 \mathrm{~d} /$ 15 treatment led to a significantly higher total chlorophyll content, and the other ebb-andflow treatments did not significantly affect total chlorophyll content (Fig. 1A).

All ebb-and-flow subirrigation treatments led to significantly lower anthocyanin contents compared with control lettuce; the $3 \mathrm{~d} /$ 15 treatment led to the highest anthocyanin content among ebb-and-flow irrigated lettuce $(0.21 \mathrm{mg} / \mathrm{g} \mathrm{FW}$; Fig. 1B).

Effects of ebb-and-flow subirrigation strategies on the nutrient contents of lettuce. Ebb-and-flow irrigation treatments led to higher ascorbic acid contents than control lettuce, although the difference between the $3 \mathrm{~d} / 15$ treatment and control plants was not significantly different (Fig. 2A).

Lettuce in the $3 \mathrm{~d} / 5$ and $3 \mathrm{~d} / 10$ treatments had significantly higher protein contents than control plants, corresponding to 1.2- and 1.1fold increases, respectively (Fig. 2B). No significant difference in soluble sugar content was observed between control plants and most ebb-and-flow subirrigation treatments, although the $2 \mathrm{~d} / 15$ treatment led a significantly lower soluble sugar content (Fig. 2C).
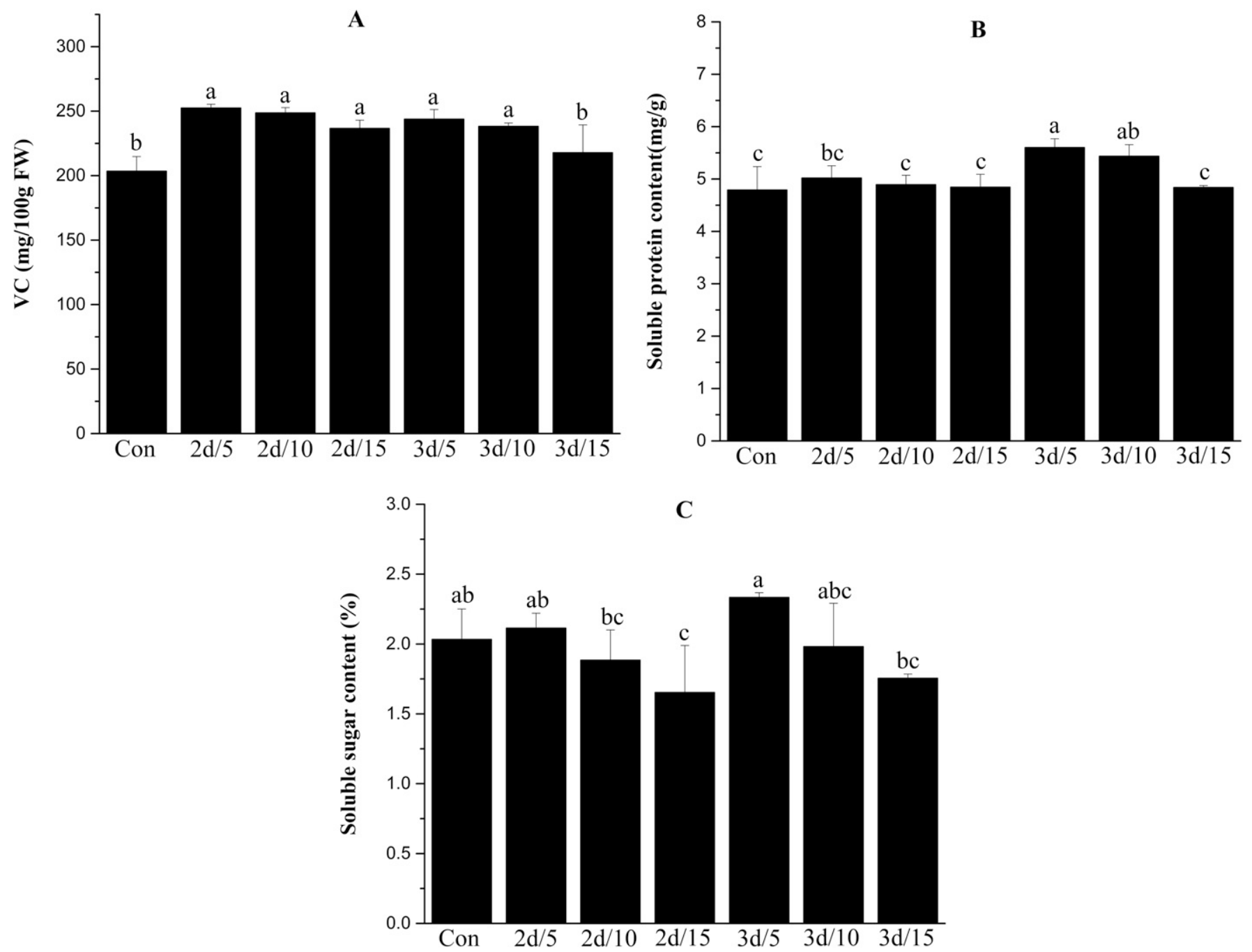

Fig. 2. Effect of different subirrigation strategies on (A) vitamin C content, (B) protein content, and (C) soluble sugar content of lettuce leaves. Control plants were subjected to overhead irrigation. Values are mean \pm SD of three replications $(n=3$ each). Different letters represent significant differences at $P<0.05$ (least significant difference analysis). 


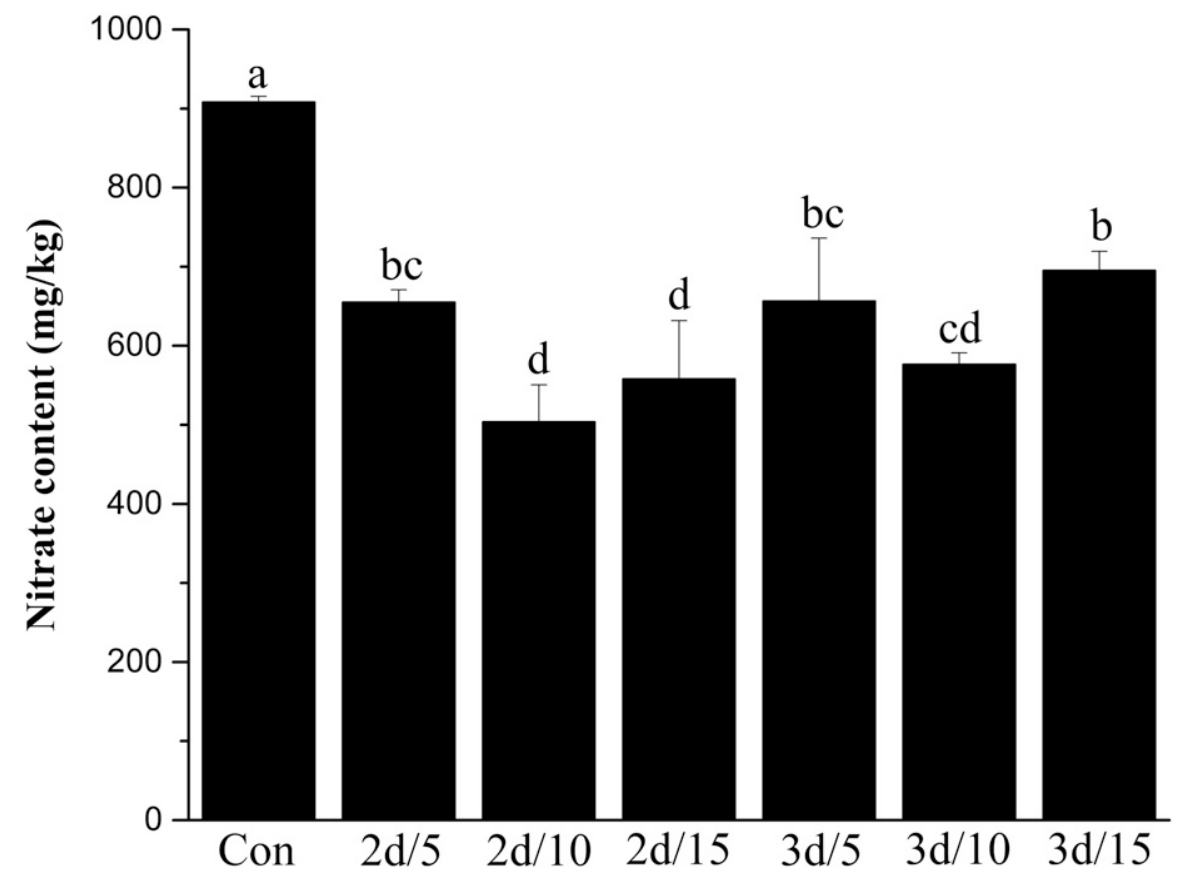

Fig. 3. Effect of different ebb-and-flow subirrigation strategies on the nitrate content of lettuce leaves. Control plants were subjected to overhead irrigation. Values are mean \pm SD of three replications $(n=3$ each). Different letters represent significant differences at $P<0.05$ (least significant difference analysis).

Effects of ebb-and-flow subirrigation strategies on the nitrate concentration of lettuce. As shown in Fig. 3, all ebb-andflow subirrigation strategies led to significantly lower nitrate concentrations compared with control lettuce plants which were irrigated overhead. The lowest nitrate concentration was observed in the $2 \mathrm{~d} / 10$ treatment (44.60\% lower than control).

\section{Discussion}

Sustainable water use mainly depends on agriculture water use. Therefore, developing a proper agricultural water management system is necessary (Shahrokhnia and Sepaskhah, 2016). Subirrigation systems have been developed to enable the more economic use of water and fertilizer, enhance crop production efficiency, and maintain crop yield. The water is directly transferred into the plant growth substrate in ebb-and-flow systems, and this technique has been proven to reduce water input in comparison with overhead irrigation (Davis et al., 2011). In this study, the ebb-and-flow subirrigation method decreased water consumption by $33 \%$ and improved water use efficiency by $20 \%$ compared with conventional overhead irrigation. Reduced water use in vegetable production is beneficial, as water costs are a major expense in greenhouse crop production.

We found the ebb-and-flow subirrigation strategies significantly increased lettuce plant growth and biomass compared with control overhead irrigation. Moreover, Pearson correlation analysis suggested the ebb-and-flow subirrigation treatments correlated positively with the FW $(r=0.86, P<0.01)$ and leaf study, ebb-and-flow subirrigation led to significantly lower anthocyanidin contents than lettuce subjected to overhead irrigation. These findings are in line with the growthdifferentiation balance hypothesis (Glynn et al., 2007), which states plants tend to favor vegetative growth under conditions of sufficient water and fertilization (e.g., the subirrigation treatments in this study) over synthesis of stress resistance compounds (e.g., anthocyanidins and flavonoids). The vital photosynthetic pigment chlorophyll is positively correlated with assimilation product accumulation (Cendrero-Mateo et al., 2015). In this study, the total chlorophyll contents of lettuce were slightly (but not significantly) higher in the $2 \mathrm{~d} / 10,2 \mathrm{~d} / 15,3 \mathrm{~d} / 5$, and $3 \mathrm{~d} / 10$ treatments, and the $3 \mathrm{~d} / 15$ treatment led to significantly higher chlorophyll accumulation. Therefore, the higher total chlorophyll contents and lower total anthocyanidin contents suggest subirrigation leads to better vegetative growth in lettuce than overhead irrigation, which partially explains the significantly higher FW of the subirrigated lettuce.

The soluble protein content was significantly higher in the $3 \mathrm{~d} / 5$ and $3 \mathrm{~d} / 10$ treatments than the other subirrigation treatments and control lettuce, indicating some soluble proteins may be induced as a protective mechanism in plants suffering water insufficiency (Bray, 1997). The subirrigation treatments significantly increased the ascorbic acid content compared with control lettuce (except in the $3 d / 15$ treatment), whereas the soluble sugar content was not significantly different between most subirrigation treatments and control lettuce. Moreover, irrigation every $3 \mathrm{~d}$ led to higher soluble sugar and protein contents than irrigation every $2 \mathrm{~d}$; and as immersion time increased, the soluble sugar, vitamin $\mathrm{C}$, and protein contents decreased. These results are in accordance with previous studies (Liu et al., 2001, 2006; Zushi and Matsuzoe, 1998) that suggested lower irrigation frequencies and volumes, which reduce soil or substrate water contents, increase nutrient levels (e.g., vitamin C and soluble sugar) in fruit.

Nitrate reductase reduces nitrate to nitrite; this reaction is thought to be the rate-limiting step of plant nitrogen assimilation. However, a relatively low water content in plants decreases nitrate reductase activity and may result in increased accumulation of nitrate (Foyer et al., 1998). In this study, ebb-andflow subirrigation led to significantly lower nitrate concentrations compared overhead irrigation; the lower water content of control plants may decrease nitrate reductase activity and lead to increased accumulation of nitrate (Foyer et al., 1998). In addition, the roots are the major site of plant nitrate assimilation. Compared with overhead irrigation, ebb-andflow subirrigation strategies led to higher numbers of roots and lower root nitrate concentrations than Pelargonium hortorum grown with overhead irrigation, suggesting plants subjected to subirrigation may have a higher capability to assimilate nitrate (Morvant et al., 1997). 
Lettuce can absorb and accumulate large quantities of nitrate that could potentially be harmful to human health (Santamaria, 2006). The products of nitrate reduction (nitrite) and conversion (nitrosamines and nitrosamides) are toxic (Umar and Iqbal, 2007). Some pediatric diseases, such as acute respiratory tract infections (Gupta et al., 2000), recurrent diarrhea (Gupta et al., 2001), and recurrent stomatitis (Gupta et al., 1999), have been associated with high nitrate consumption. Moreover, consumption of high levels of nitrate has negative effects on cardiac muscles, adrenal glands, lung alveoli, and the immune system in humans (Gupta et al., 2006; Ustyugova et al., 2002), and is associated with infant mortality, hypothyroidism, and diabetes (Gupta et al., 2006). Excitingly, we found the ebb-and-flow subirrigation treatments significantly decreased the total nitrate concentration in lettuce compared with overhead irrigation. Thus, subirrigation strategies could potentially benefit human nutrition by enabling the production of lettuce with low nitrate levels.

Based on plant growth characteristics, FW and DW, nutritional value, and nitrate content, the $3 \mathrm{~d} / 15$ treatment (irrigation every $3 \mathrm{~d}, 15$ min immersion) was the optimal ebband-flow subirrigation strategy for lettuce cultivation. This irrigation strategy led to the highest FW, a high total chlorophyll content, high concentrations of nutrients (such as vitamin $\mathrm{C}$, soluble proteins, and sugars), and moderate anthocyanidin and nitrate contents. Further investigation of this subirrigation strategy in leafy vegetable production is required before this system can be used operationally. For instance, strategies to avoid the potential spread of root-infesting pathogens during cultivation and the optimal conditions (including lighting, fertigation, plant growth regulators and pesticides) for lettuce production need to be determined.

\section{Conclusion}

Ebb-and-flow subirrigation significantly increased plant growth and vitamin $\mathrm{C}$ contents and significantly decreased the nitrate content of lettuce. We found that a $15-\mathrm{min}$ immersion every $3 \mathrm{~d}$ was the optimal ebband-flow subirrigation treatment; this strategy could potentially be used in commercial lettuce production.

\section{Literature Cited}

Ahmed, A.K., G.C. Cresswell, and A.M. Haigh. 2000. Comparison of sub-irrigation and overhead irrigation of tomato and lettuce seedlings. J. Hort. Sci. Biotechnol. 75:350-354.

Argo, W.R. and J.A. Biernbaum. 1995. The effect of irrigation method, water-soluble fertilization, preplant nutrient charge, and surface evaporation on early vegetative and root growth of poinsettia. J. Amer. Soc. Hort. Sci. 120:163-169.

Bray, E.A. 1997. Plant responses to water deficit. Trends Plant Sci. 2:48-54.
Cendrero-Mateo, M.P., M.S. Moran, S.A. Papuga, K. Thorp, L. Alonso, J. Moreno, G. PonceCampos, U. Rascher, and G. Wang. 2015. Plant chlorophyll fluorescence: Active and passive measurements at canopy and leaf scales with different nitrogen treatments. J. Expt. Bot. 67:275-286.

Chalker-Scott, L. 1999. Environmental significance of anthocyanins in plant stress responses. Photochem. Photobiol. 70:1-9.

Cheng, D.M., N. Pogrebnyak, P. Kuhn, A. Poulev, C. Waterman, P. Rojas-Silva, W.D. Johnson, and I. Raskin. 2014. Polyphenol-rich Rutgers Scarlet Lettuce improves glucose metabolism and liver lipid accumulation in diet-induced obese C57BL/6 mice. Nutrition 30:S52-S58.

Cui, X.X., X. Yang, H.J. Wang, X.Y. Rong, S. Jing, Y.H. Xie, D.F. Huang, and C. Zhao. 2017. Luteolin-7-O-glucoside present in lettuce extracts inhibits hepatitis B surface antigen production and viral replication by human hepatoma cells in vitro. Front. Microbiol. 8:2425.

Davis, A.S., M.M. Aghai, J.R. Pinto, and K.G. Apostol. 2011. Growth, gas exchange, foliar nitrogen content, and water use of subirrigated and overhead-irrigated Populus tremuloides Michx. seedlings. HortScience 46:1249-1253.

Ferrarezi, R.S., M.W. van Iersel, and R. Testezlaf 2015b. Monitoring and controlling ebb-andflow subirrigation with soil moisture sensors. HortScience 50:447-453.

Ferrarezi, R.S., G.M. Weaver, M.W. van Iersel, and R. Testezlaf. 2015a. Subirrigation: Historical overview, challenges, and future prospects. HortTechnology 25:262-276.

Foyer, C.H., M.H. Valadier, A. Migge, and T.W. Becker. 1998. Drought-induced effects on nitrate reductase activity and mRNA and on the coordination of nitrogen and carbon metabolism in maize leaves. Plant Physiol. 117:283-292.

Francisco, M., P. Velasco, D.A. Moreno, C. García-Viguera, and M.E. Cartea. 2010. Cooking methods of Brassica rapa affect the preservation of glucosinolates, phenolics and vitamin C. Food Res. Intl. 43:1455-1463.

Glynn, C., D.A. Herms, C.M. Orians, R.C. Hansen, and S. Larsson. 2007. Testing the growthdifferentiation balance hypothesis: Dynamic responses of willows to nutrient availability. New Phytol. 176:623-634.

Gupta, S.K., R. Gupta, A. Seth, A. Gupta, J. Bassin, D. Gupta, and S. Sharma. 1999. Epidemiological evaluation of recurrent stomatitis, nitrates in drinking water, and cytochrome $b_{5}$ reductase activity. Amer. J. Gastroenterol. 94:18081812.

Gupta, S.K., R.C. Gupta, and A. Gupta. 2006. Nitrate toxicity and human health. Proc. Wkshp. Nitrogen Environ., Ind. and Agr., New Delhi, India.

Gupta, S.K., R.C. Gupta, A.B. Gupta, A.K. Seth, J.K. Bassin, and A. Gupta. 2000. Recurrent acute respiratory tract infections in areas with high nitrate concentrations in drinking water. Environ. Health Perspect. 108:363-366.

Gupta, S.K., R.C. Gupta, A.B. Gupta, A.K. Seth, J.K. Bassin, A. Gupta, and M.L. Sharma. 2001. Recurrent diarrhea in children living in areas with high levels of nitrate in drinking water. Arch. Environ. Health 56:369-373.

Hicklenton, P.R. and K.G. Cairns. 1996. Plant water relations and mineral nutrition of containerised nursery plants in relation to irrigation method. Can. J. Plant Sci. 76:155-160.

Holcomb, E.J., S. Gamez, D. Beattie, and G.C. Elliott. 1992. Efficiency of fertigation pro- grams for Baltic Ivy and Asiatic Lily. HortTechnology 2:43-46.

Li, M.L., L.Y. Chang, K. Zhang, and D.F. Huang. 2014. Effects of different irrigation amounts on pakchoi growth and quality. J. Changjiang Veg. 10:27-31 [in Chinese].

Lin, Y. 1989. Comparison and improvement of several common anthrone-colorimetric methods for sugar content in plant. Plant Physiol. Commun. 4:53-55 [in Chinese].

Liu, C.W., Y. Sung, B.C. Chen, and H.Y. Lai. 2014. Effects of nitrogen fertilizers on the growth and nitrate content of lettuce (Lactuca sativa L.). Intl. J. Environ. Res. Public Health 11:4427-4440.

Liu, H.T., H.Y. Qi, Y. Liu, and G.X. Shi. 2006. Effects of different water deficit levels on the growth and development, yield and quality of tomato. J. Shenyang Agr. Univ. 37:414-418 [in Chinese].

Liu, M., K. Takayuki, T. Munehiro, and H. Chen. 2001. Effects of soil moisture on plant growth and fruit properties of strawberry. Acta Hort. Sinica 28:307-311 [in Chinese].

Morvant, J.K., J.M. Dole, and E. Allen. 1997. Irrigation systems alter distribution of roots, soluble salts, nitrogen, and $\mathrm{pH}$ in the root medium. HortTechnology 7:156-160.

Pepe, G., E. Sommella, M. Manfra, M. De Nisco, G.C. Tenore, A. Scopa, A. Sofo, S. Marzocco, S. Adesso, T. Novellino, and P. Campiglia. 2015. Evaluation of anti-inflammatory activity and fast UHPLC-DAD-IT-TOF profiling of polyphenolic compounds extracted from green lettuce (Lactuca sativa L.; var. Maravilla de Verano). Food Chem. 167:153-161.

Powell, W., C. Catranis, and C. Maynard. 2000. Design of self-processing antimicrobial peptides for plant protection. Lett. Appl. Microbiol. 31:163-168.

Qadir, O., M. Siervo, C.J. Seal, and K. Brandt. 2017. Manipulation of contents of nitrate, phenolic acids, chlorophylls, and carotenoids in lettuce (Lactuca sativa L.) via contrasting responses to nitrogen fertilizer when grown in a controlled environment. J. Agr. Food Chem. 65:10003-10010.

Santamaria, P. 2006. Nitrate in vegetables: Toxicity, content, intake and EC regulation. J. Sci. Food Agr. 86:10-17.

Shahrokhnia, M.H. and A.R. Sepaskhah. 2016. Effects of irrigation strategies, planting methods and nitrogen fertilization on yield, water and nitrogen efficiencies of safflower. Agr. Water Mgt. 172:18-30.

Soundy, P., D.J. Cantliffe, G.J. Hochmuth, and P.J. Stoffella. 2001a. Nutrient requirements for lettuce transplants using a floatation irrigation system. I. Phosphorus. HortScience 36:10661070.

Soundy, P., D.J. Cantliffe, G.J. Hochmuth, and P.J. Stoffella. 2001b. Nutrient requirements for lettuce transplants using a floatation irrigation system II. Potassium. HortScience 36:10711074.

Tavarini, S. and L.G. Angelini. 2013. Stevia rebaudiana Bertoni as a source of bioactive compounds: The effect of harvest time, experimental site and crop age on steviol glycoside content and antioxidant properties. J. Sci. Food Agr. 93:2121-2129.

Thomas, B. 1993. Overview of the speedling, incorporated, transplant industry operation. HortTechnology 3:406-408.

Umar, S. and M. Iqbal. 2007. Nitrate accumulation in plants, factors affecting the process, and human health implications. A review. Agron. Sustain. Dev. 27:45-57. 
United Nation Food and Agriculture Organization. 2016. Production/yield quantities of lettuce and chicory in world. 26 Feb. 2018. <http://www. fao.org/faostat/en/\#data/QC/visualize>.

Ustyugova, I., C. Zeman, K. Dhanwada, and L. Beltz. 2002. Nitrates/nitrites alter human lymphocyte proliferation and cytokine production. Arch. Environ. Contam. Toxicol. 43:270-276.

Wang, J., S. Gong, and Y. Yu. 2008. Effect of surface irrigation frequency on soil water and temperature as well as growth of spring maize. J. Hydraul. Eng. 39:500-505 [in Chinese].

Wang, X. and S. Xing. 2009. Determination of protein quantitation using the method of coomassie brilliant blue. Tianjin Chem. Ind 23:40-42 [in Chinese].

Xu, F., L. Ye, W. Xu, and J. Zheng. 2010. Comparison of methods of chlorophyll extraction in Chinese cabbage. Northern Hort. 34:32-34 [in Chinese].

Yang, X., X.X. Cui, L. Zhao, D. Guo, L. Feng, S.S Wei, C. Zhao, and D.F. Huang. 2017. Exogenous glycine nitrogen enhances accumulation of glycosylated flavonoids and antioxidant activity in lettuce (Lactuca sativa L.). Front. Plant Sci. 8:2098.

Yang, Z. 2007. Anthocyanin content in mulberry red pigment by $\mathrm{pH}$-differential spectrophotometry. Food Sci. Technol. 32:201-203 [in Chinese].

Zushi, K. and N. Matsuzoe. 1998. Effect of soil water deficit on vitamin $\mathrm{C}$, sugar, organic acid, amino acid and carotene contents of largefruited tomatoes. J. Jpn. Soc. Hort. Sci. 67:927-933. 